15. Reports on implementation of the Association agreement between Ukraine and the EU (2019). URL: https:/www.kmu.gov.ua/diyalnist/yevropejska-integraciya/vikonannyaugodi-pro-asociaciyu/zviti-pro-vikonannya-ugodi-pro-asociaciyu (in Ukrainian).

16. Conception of state policy on development and protection of economic competition in Ukraine (draft) (2019). Antimonopoly Committee of Ukraine, 24 p. URL: http://www. amc.gov.ua/amku/doccatalog/document? $i d=146848 \&$ schema=main (in Ukrainian).

Матеріал надійшов до редакиіï 15.01.2021 p.

УДК 32.019.51

\title{
Андрій Гачкевич,
}

кандидат юридичних наук, доцент кафедри міжнародної інформації,

Національний університет «Львівська політехніка»,

ORCID ID 0000-0001-7520-7426

andrii.o.hachkevych@1pnu.ua

\section{Влада Сірош,}

бакалаврант кафедри міжнародної інформації,

Національний університет «Львівська політехніка»,

ORCID ID 0000-0003-0868-3224

vlada.sirosh.mv.2017@1pnu.ua

\section{Анна Шевчук,}

бакалаврант кафедри міжнародної інформації,

Національний університет «Львівська політехніка»,

ORCID ID 0000-0002-6554-2287

anna.shevchuk.mv.2017@1pnu.ua

DOI 10.29038/2524-2679-2021-01-358-370

\section{ТЕОРЕТИКО-МЕТОДОЛОГІЧНІ ОСНОВИ ВИКОРИСТАННЯ ДЕРЖАВАМИ БРЕНДИНГУ ТА РЕПУТАЦЙНОГО МЕНЕДЖМЕНТУ ЯК ІНСТРУМЕНТІВ УПРАВЛІННЯ ПРИВАТНИМИ КОМПАНІЯМИ}

У статті вивчено процеси управління такими нематеріальними ресурсами держави, як бренд та репутація. Брендинг і репутаційний менеджмент уже тривалий час використовуються для підвищення успішності приватних компаній, а віднедавна й для розвитку могутності держав на міжнародній арені. Водночас наявність істотних відмінностей між обома суб'єктами зумовлює потребу в розробиі інших підходів до зміцнення авторитету держав, ніж просування компаній на ринках. Зважаючи на 
цุі відмінності, досліджуємо бренд та репутацію як об’єкти управління, а також розглядаємо їхню багатогранну природу. У статті порушено питання співвідношення національного бренду та державної репутації, ураховуючи загальнонаукове значення вихідних понять. Наведено пояснення національного брендингу й репутаційного менеджменту. Описано окремі теоретико-прикладні проблеми, щзо виникають за застосування інструментарію управління нематеріальними ресурсами держави, зокрема визначення изільової аудиторії. Результати дослідження можуть бути цінними для вчених, які прагнуть кращзе зрозуміти природу національного бренду та державної репутайії, а також представників органів державної влади, котрі в ідеалі мали би бути зачікавлені в тому, щуоб ефективно управляти ними в інтересах усього населення.

Ключові слова: національний брендинг, національний бренд, репутаційний менеджмент, державна репутація.

\section{1. ВСТУП}

Постановка проблеми. Наслідком глобалізаційних процесів, в основу яких покладено всебічну інтеграцію держав, стало посилення конкуренції між ними. Держави змагаються між собою за інвесторівмільярдерів, міжнародні туристичні потоки, членство в авторитетних організаціях, прихильність найвпливовіших політичних лідерів світу тощо. Багато в чому їх конкурування схоже на боротьбу приватних компаній за глобальний ринок. За таких умов для отримання переваг на універсальному рівні йдеться не лише про економічну сферу, останнім часом усе частіше різні держави роблять спроби використовувати інструментарій приватних компаній. Однак істотна відмінність між сутністю обох видів суб'єктів вимагає внесення поправок до арсеналу засобів для зміцнення авторитету держави на міжнародній арені. Серед понять, які давно увійшли до вжитку у світі бізнесу та поступово набувають поширення у сфері державної політики, особливе місце займають національний бренд та репутація держави. Від ефективності управління кожним із них залежить те, наскільки впливовою є та чи інша держава у світі. Водночас навіть для експертів у сферах репутаційного й бренд-менеджменту, які займалися розвитком успішності приватних компаній, залучення до процесів, пов'язаних із брендом та репутацією держав, вимагає ознайомлення 3 явищем міжнародних відносин i категорією держав як їхніх основних суб' єктів. У цій статті, ураховуючи особливості держав, нематеріальні ресурси яких підлягають управлінню за допомогою процесів, зазначених у назві, вивчаються важливі 
особливості кожного з них, що може бути цінними не лише для вчених, а й для представників органів державної влади, стурбованих тим, щоб їхня держава розвивала свою могутність. Актуальність обраної теми зумовлена тим, що, незважаючи на гостру потребу в знаннях про грамотне представлення держави у світі, за аналогією 3 приватними компаніями, залишається чимало питань без відповідей, наприклад, те як співвідносяться між собою згадані в назві статті процеси.

Аналіз останніх досліджень і публікацій. Відзначимо, що тема статті стосується низки теоретико-прикладних аспектів, які вивчаються різними суспільними науками. Ураховуючи напрацювання вітчизняних учених, можемо виокремити декілька контекстів. По-перше, вона стосується бренду та репутації як об'єктів управління. У загальноекономічному розумінні ці категорії розглядалися з різних сторін і в різних контекстах. Відзначимо існування плюралізму думок із приводу їх співвідношення, а також інтерпретацій понятійного ряду «бренд - імідж - образ - репутація». По-друге, цими питаннями дедалі частіше цікавилися представники політологічної науки, які досліджували поняття національного бренду та державної репутації. До них належать такі українські вчені, як О. Свтушенко та I. Присяжненко (концепт брендингу держави в політичній науці), К. Савон (порівняльна характеристика бренду, іміджу, образу та репутації держави), Т. Федорів (категорії репутації країни й державного брендингу в науці державного управління), А. Штельмашенко (значення терміна «бренд держави» в політології) та ін. По-третє, тема статті споріднена 3 дослідженнями у сфері міжнародних відносин, зокрема ці інструменти стосуються таких явищ, як «м'яка сила» й публічна дипломатія. На сучасному етапі від ефективності їх застосування залежить авторитет держави у світі. По-четверте, репутаційний менеджмент і брендинг викликає інтерес крізь призму забезпечення національних інтересів України за кордоном. Сильний національний бренд України та ії хороша репутація $є$ тими цінностями, які об'єднують велику кількість учених і вимагають консолідованих зусиль політичної еліти для їх просування у світі. По-п'яте, обидва процеси, згадані в назві статті, належать до управлінських, а отже, важливу роль у їх вивченні відіграють дослідження в галузі менеджменту, завдяки ознайомленню 3 результатами яких управління нематеріальними ресурсами держави може відбуватися більш ефективно. Відзначимо, що кількість праць, щодо національного бренду та репутації держави стрімко зростає. Зазвичай, відповідні дослідження мають міждисциплінарний характер і показують, наскільки багатогранною є ця тема та відкритою до різних поглядів і нових концепцій. Додамо, що в одному з попередніх номерів цього 
журналу опубліковано статтю про ідентичний підхід до національного брендингу, де представлено короткий огляд деяких вітчизняних й іноземних публікацій останніх років за її темою [1, с. 59].

Мета статті - висвітлити теоретико-методологічні аспекти національного брендингу та репутаційного менеджменту, ураховуючи специфіку держави як суб'єкта. Важливими завданнями на шляху до поставленої мети стали розгляд етимології термінів «національний бренд» і «державна репутація» та їх співвідношення; охарактеризування брендингу й репутаційного менеджменту як проявів управлінської діяльності, порушення низки теоретико-прикладних проблем, що виникають у процесі національного брендингу та репутаційного менеджменту.

\section{2. РЕЗУЛЬТАТИ ДОСЛІДЖЕННЯ}

Незважаючи на те, що поняття бренду держави й державної репутації часто використовують в одному контексті, щоб позначити їі могутність на міжнародній арені, престиж та авторитет, і сприймаються як синонімічні, між ними існує низка відмінностей. Задля дослідження їх співвідношення можемо розглянути етимологію обох термінів та охарактеризувати визначення. Термін «бренд» походить від давньоскандинавського слова brandr, яке в перекладі українською мовою означає «випалювати». С. Кхан й О. Муфті в статті «Гаряча історія та холодне майбутнє брендів» пояснюють, що вживання цього слова стосується традиції випалювання клейма на шкірі худоби розпеченим залізом. За допомогою нього власники худоби позначали своїх тварин - господарства мали унікальні символи, завдяки яким захищалося право власності, якщо тварини губилися чи їх викрадали $[2$, c. 75-76]. Можемо зауважити, що, як і теперішний бренд, кожне клеймо повинно було бути простим, унікальним і впізнаваним. Поняття репутації походить від латинського reputatio, що означає «роздуми», «споглядання» [3]. Дуже промовисте пояснення походження терміна від re та putare «знову» та «думаю» (латинська мова). На відміну від слова «бренд», значення якого зазнало істотної еволюції з плином часу, «репутація», як і в минулому, у наш час стосується думки про когось, що формується на підставі досвіду й матеріалізується в певних очікуваннях. Ще в епоху Стародавньої Греції Арістотель пов'язував репутацію із серйозністю людини та наявністю в неї добропорядності й інтелекту [4, с. 12].

Окремі підказки для розкриття співвідношення цих понять знаходимо у двох найпростіших визначеннях: «бренд - це те, як сприймають когось або щось» (образ у голові), а «репутація - це те, що про когось 
або щось думають» (інтелектуальна оцінка). В обох випадках ідеться про відображення у свідомості одного суб'єкта образу іншого. Ним може бути компанія (корпоративний бренд), держава (національний бренд), людина (персональний бренд) тощо. Первісними об'єктами бренду були товари та послуги. Бренд відзначається інтелектуальним й емоційним забарвленням та уособлює сприйняття різними способами, тоді як репутація - інтелектуальним, що проходить «сито» раціоналізації. Крім того, бренд може створюватися завдяки зусиллям відповідного суб' єкта або з його ініціативи іншими суб'єктами (стосовно того, чи існує бренд тоді, коли його свідомо не створювали, можливі різні думки), тоді як репутація здебільшого формується сама по собі та меншою мірою підлягає свідомому управлінню. Безумовно, на неї впливає поведінка суб'єкта, що формує позитивний або негативний досвід взаємодії з ним. Водночас в епоху інформаційного суспільства твердження про повний контроль держави над своєю репутацією, як і приватної компанії чи навіть фізичної особи, уже не видається таким безапеляційним. Розповсюдження фейків через соціальні мережі дає можливість за короткий період часу зіпсувати репутацію держави, навіть якщо в майбутньому їх правдивість буде спростована («для того, щоб створити репутацію, потрібно двадцять років, і всього лиш за п'ять хвилин ії можна зруйнувати»- В. Баффет). Для брендів характерна позитивна конотація, вони втілюють у собі характерні риси того чи іншого суб'єкта та узагальнюють стійкі асоціації 3 ним. Виникнення певного образу суб'єкта в голові не породжує його інтелектуальної оцінки, відповідності раціональним очікуванням, а швидше створює відповідну емоційно-ментальну конструкцію. Далеко не завжди ці асоціації виставляють його в гарному світлі перед усіма людьми. Щоправда, демонстрація бренду $\epsilon$ планомірною та зосереджується переважно на належному сприйнятті цільовою аудиторією. Бренд $є$ таким, яким його формують, у той час як репутація - або хорошою, або поганою. Український учений 3. Дахній описує ситуацію, коли уряд Сполученого Королівства вдався до «навмисного псування» державної репутації, коли в ЗМІ з'являлися часті згадки про високий рівень безробіття та жахливу погоду [4, с. 14]. Тим самим можновладці намагалися призупинити міграційні процеси з країн Центральної й Східної Свропи. Зауважимо, що через подібні повідомлення здійснювався вплив і на бренд Сполученого Королівства. Вони були здатними зробити більш стійкими асоціації різних суспільних груп з особливими атмосферними умовами та з місцями для туристичного відвідування, а не працевлаштування.

Американська асоціація маркетингу запропонувала тлумачити 
бренд таким чином: назва, фраза, оформлення, символ або будь-яка інша ознака, яка відрізняє товари чи послуги одного продавця від інших [5]. Водночас фінські вчені Н. Мальмелін та Дж. Хакала у праці «Радикальний бренд» зауважили, що таке традиційне розуміння, яке прирівнює бренд до торговельної марки й охоплює «відчутні» (tangible) відображення товарів і послуг, а також приватних компаній, вимагає переосмислення. На їхню думку, сьогодні актуальним більш цілісне визначення бренду як усього того, що робить компанія. Можемо виокремлювати різні категорії, придатні для оцінки, що стосуватимуться й самої компанії, й органів управління нею, і працівників та ін. Так само доцільно мати на увазі не лише те, до чого можна доторкнутися, а й невідчутне, невидиме (intangible) $[6$, c. 9]. Як вони слушно відзначають, розуміння поняття бренду завжди було неоднозначним. Крім того, вихід держав на поле для змагань брендів дав черговий поштовх до переосмислення його сутності, що бере свої витоки від традиції випалювання клейма на шкірі худоби. Приклад держав показує, що обмежувати розуміння бренду торговельною маркою не доцільно, натомість більш доречно розширити уявлення про бренд за рахунок усього того, що споріднене $з$ державою та є значущим для інших країн. Саме на таких підходах грунтується шестикутник С. Анхольта. Водночас формування єдиного образу держави як бренду $€$ надзвичайно складним завданням, а дані проведених соціологічних опитувань демонструють, наскільки по-різному одну й ту саму державу можуть сприймати окремі категорії населення навіть в одній країні. Онлайн-опитування 3 приводу представлення України у світі проведене серед населення п’яти провідних держав Свропейського Союзу у 2010 р. Результати опитування дають підставу зробити висновок, що рівень обізнаності про Україну був різним (найвищий - в Італії, найнижчий у Франції; люди віком 21-40 р. знали найбільше з-поміж усіх вікових категорій) [7]. Як бачимо, особливості сприйняття держав людиною $\epsilon$ дуже індивідуальними. Вона має свій особистий досвід, систему цінностей, світогляд, що формують певний образ у іiі свідомості. Та це не означає, що кожен сам створює сотні чи навіть тисячі брендів своєю уявою, адже бренд - це відносно стійкі особливості відображення образу одного суб'єкта у свідомості великої кількості інших. Не менш цікавою для вивчення є також категорія репутації. На відміну від бренду, яким здебільшого займаються маркетологи, реалізовуючи свої креативні ідеї, питання репутації мають безпосередній стосунок i до експертності юристів. Справи про захист репутації регулярно розглядаються судами після того, як з ініціативи конкурентів добре ім'я 
приватної компанії було заплямоване. Цікаво, що подібні справи можуть порушуватись і за позовами фізичних осіб, а перед суддями постає необхідність оцінити репутацію як об'єктивну категорію. Водночас, якщо для приватних компаній хороша репутація означає високу довіру партнерів та виявлення ними намірів здійснювати співробітництво, то що вона може означати для держав? Репутація держави - «більшменш усталена думка різних груп внутрішніх і зовнішніх зацікавлених сторін про цю країну, яка формується на основі оцінки їі природних достоїнств та поведінки iï населення» [8, с. 102]. Репутація залежить від великої кількості параметрів, на підставі яких формуються «судження і установки суспільних верств щодо конкретної держави». Предметом таких суджень й установок $€$ зовнішньо- та внутрішньополітична діяльність держави, владні еліти, політичний режим, політична культура, електоральна поведінка, стиль управління економікою й суспільством, правова культура, ідеологія тощо [9, с. 20]. Схоже на те, що хороша репутація проявляється в довірі до представників держави як організації політичної влади, а також прихильності до іiі населення. Водночас не завжди сама держава прагне мати хорошу репутацію в певному регіоні чи навіть серед держав-сусідів.

Під брендингом або бренд-менеджментом, що в цій статті розглядаються як однакові поняття, розуміють діяльність, спрямовану на створення бренду, а також на його вдосконалення відповідно до наявних очікувань. Серед визначень національного брендингу, що представлені в науковій літературі, заслуговує на увагу таке: «процес, за допомогою якого можна створювати, змінювати імідж країни, спостерігати за ним, а також оцінювати його та ефективно керувати ним для покращення репутації держави серед цільової міжнародної аудиторії» [10, с. 101]. Репутаційний менеджмент можна загалом визначити так само, змінюючи лише об'єкт діяльності на репутацію («управління процесом формування та коригування репутаційних й іміджевих характеристик, а також доведення їх до цільової аудиторії» [11, с. 6]). Водночас, на нашу думку, поняття репутаційного менеджменту також ураховує підтримку репутації на належному рівні, що передбачає адекватне реагування на репутаційні ризики та загрози. На відміну від процесу управління брендом держави, відомим як національний брендинг, спеціального терміна щодо управління репутацією держави досі не існувало. Такий стан речей свідчить, що управління репутацією держави $є$ відносно новим інструментом розвитку їі могутності та маловивченим (terra incognita у сфері державного управління [12, с. 90]), тоді як результати 
досліджень про національний брендинг з'являються доволі часто, у більшій кількості, а їхні автори подекуди пишуть не лише про вплив на бренд держави у значенні образу в голові, а й на репутацію як на інтелектуальну оцінку. Водночас репутаційний менеджмент держави як окрему наукову категорію розглядала Т. Федорів у своїй докторській дисертації та низці статей. Вона запропонувала визначати це поняття у сфері державного управління як «сукупність інструментів професійного управління основними характеристиками держави (брендинг, бенчмаркінг, паблік рілейшнз, іміджмейкінг, державна реклама, стейкхолдер-менеджмент), за допомогою яких можна зміцнити репутаційну платформу суб'єкта» [12, с. 93]. Водночас можемо додати, що поняття репутаційного менеджменту держави, яке пояснює Т. Федорів відносить до його суб'єктів саму державу, гілки влади, органи державної влади, органи місцевого самоврядування, державних службовців як професійну спільноту, інших представників влади, які уособлюють собою державу чи окремий їі суб'єкт [12], стосується розуміння держави як організації політичної влади, а не сукупності таких елементів, як населення, територія й влада. Зв'язок між національним брендингом та управлінням державною репутацією полягає в тому, що побудова сильного бренду держави забезпечує покращення іiі репутації на міжнародній арені. Водночас неспроможність держави відреагувати адекватно на репутаційні ризики створюють виклики для національного брендингу. Отже, національний брендинг та репутаційний менеджмент $\epsilon$ взаємопов'язаними. За словами Дж. Вінсенте, державний брендинг став основним інструментом для досягнення конкурентоспроможності країни, оскільки наявність поганої репутації або ж ії̈ повна відсутність негативно впливає на можливості держави вести конкурентну боротьбу в будь-якій сферi $[13$, c. 1$]$.

Застосування інструментарію для зміцнення авторитету країни у світі, зокрема національного брендингу та бренд-менеджменту, органами державної влади порушує низку теоретико-прикладних проблем. Вони розглядаються далі з урахуванням спільних і відмінних характеристик держави й приватної компанії. По-перше, різні позиції з-поміж політиків та вчених породжує визначення мети обох досліджуваних процесів. Саме від неї залежить стратегічне бачення реалізації політики бренд-менеджменту й репутаційного менеджменту. У випадку приватної компанії така мета випливає з ії загального призначення, яким переважно $є$ отримання прибутку (це - досягнення певного соціального ефекту). Припускаємо, що для держави такою метою може бути розвиток могутності або 
посилення авторитету на міжнародній арені. Водночас високий ступінь абстрактності цих категорій і неспроможність оцінити їх об'єктивно без допомоги спеціальних міжнародних рейтингів, що укладаються останнім часом, наводить на певні сумніви щодо правильності цього припущення. Як показує практика, поштовх до управління брендом та репутацією держави в певний момент дають ті чи інші виклики (або навіть загрози), для подолання яких застосовуватимуться відповідні дії (це підтверджує описана раніше ситуація зі Сполученим Королівством). У зв'язку з цим більш доцільно говорити про окремі інформаційні кампанії як системи заходів впливу на визначені групи стейкхолдерів шляхом створення, розповсюдження або приховування відповідної інформації. Для приватних компаній діяльність із брендингу й репутаційного менеджменту має постійний та керований характер, хоча й може передбачати проведення окремих інформаційних кампаній для виконання додаткових завдань, для держав - вона є епізодичною та ситуативною.

По-друге, залишається не до кінця зрозумілим, хто саме є суб'єктом управління. Зрештою, твердження про те, що народ є носієм державної влади, вимагає конкретизації щодо національного брендингу й репутаційного менеджменту. Якщо зважати на Конституцію України, то вже іiі положення дають підставу покласти відповідальність за обидва процеси на такі органи, як Верховна Рада України (п. 3, 5, 6 ст. 85), Президент України (п. 3 ст. 106), Кабінет Міністрів України (п. 3, 4 ст. 116). Проблема ідентифікації суб'єкта управління не є настільки малозначимою, щоб не приділяти їй жодної уваги, адже зміна владної еліти після чергових виборів породжує іншу візію національного бренду чи державної репутації (або навіть відсутність будь-якої візіі). Нові вибори можуть стати загрозливими для забезпечення послідовності як важливої ознаки сильного бренду, а також сформованої роками або навіть десятиріччями репутації. У приватній компанії на управління брендом й репутацією можуть впливати головні керівники - власник (де факто) та СЕО (де юре), тоді як відповідними стратегіями та їхньою реалізацією займаються окремі підрозділи й фахівці, відповідальні за маркетинг. Інколи ці функції делегуються на підставі аутсорсингу. Щоправда, сучасні тенденції демонструють, що розробка та здійснення корпоративної політики у сфері брендингу й репутації стають дедалі важливішими для просування компанії на ринку та вимагають постійних зусиль й інтегрованості в іiі організаційну структуру. Чи доцільно сприймати зміну державної політики щодо брендингу й репутаційного 
менеджменту після зміни владної еліти як прояв ребрендингу, до якого нерідко вдаються приватні компанії? Якщо такі зміни відбуваються спонтанно, то ні. Водночас прихід до влади політичної партії, яка проголошує певні цінності та декларує певні ідеї, сам по собі, безумовно, відобразиться й на сприйнятті цієї держави у світі. Ефективний ребрендинг вимагає налагоджування зв'язків із попереднім станом речей, його всебічний аналіз та поступову корекцію, в основу якої покладено фахову стратегічну думку.

По-третє, на роздуми наводить визначення цільової аудиторії. Бренд приватної компанії, зазвичай, «калібрується» під потенційних споживачів ㄲï продукції, працівників, а також бажаних партнерів по бізнесу. Успішність компанії залежить від того, яку репутацію вона має в очах усіх вищенаведених категорій. Під час створення та реалізації репутаційних і бренд-стратегій приватних компаній фахівці створюють портрет цільової аудиторії, вивчаючи іiі звички, бажання, потреби. Водночас визначення цільової аудиторії для держави (або кола стейкхолдерів) є набагато складнішим завданням, оскільки охоплює різні категорії осіб з інших держав, а також власних громадян: ту частину населення, яка може бути зацікавлена в туристичних подорожах їі пам'ятними місцями; осіб, котрі прагнуть працевлаштуватися на iii території; інвесторів, які намагаються розширити свій бізнес у ній, політиків, відповідальних за прийняття рішень щодо міжнародного співробітництва з нею тощо. Досліджуючи можливі цільові аудиторії, Ф. Котлер та співавтори в праці «Маркетинг визначає місце Свропи» виокремлюють такі чотири категорії: відвідувачі, мешканці, бізнес і виробники [14].

\section{3. ВИСНОВКИ ТА ПЕРСПЕКТИВИ ПОДАЛЬШИХ ДОСЛІДЖЕНЬ}

Терміни «бренд» та «репутація», хоч i в наш час уживаються як дуже близькі за значенням, однак відрізняються між собою в етимологічному плані. Перший із них сформувався для позначення виділення серед інших завдяки наявним особливостям; другий - оцінки якостей та діяльності, що впливає на ступінь довіри. Національний бренд i державна репутація є важливими нематеріальними ресурсами, що визначають рівень іiі могутності у світі, а також показниками міжнародного авторитету. Водночас змістове наповнення обох понять залишається доволі дискусійним і характеризується науковим плюралізмом. I брендинг, i репутаційний менеджмент належать до 
управлінських процесів, які потребують стратегічного підходу та врахування специфіки конкретної держави. Порівняння приватної компанії й держави дало підставу сформулювати низку теоретикоприкладних проблем, що виникають у процесі використання брендингу та репутаційного менеджменту органами державної влади. Ці проблеми стосуються питань «кому управляти», «для чого управляти» і «хто $\epsilon$ цільовою аудиторією». Отже, акценти в національному брендингу ставляться на тому, щоб сформувати необхідне сприйняття держави у світі, яке позначається терміном «національний бренд». Водночас, на відміну від тих повноважень, які чітко визначені для органів державної влади в інших сферах внутрішньої та зовнішньої політики, шлях до сильного бренду держави не регламентований на рівні законів. Брендстратегії $є$ результатом симбіозу аналітичної й творчої діяльності та повинні враховувати особливості конкретного випадку. Відзначимо, що формування сильних брендів приватних компаній відбувається роками, тоді як держав - ще довше. Натомість зміна владної еліти, що спричиняє нове бачення представлення держави на міжнародній арені, може вплинути на іiї брендинг як позитивно, якщо підтримка основних елементів бренду надалі забезпечуватиметься, так і негативно, коли від неї відмовлятимуться (скажімо, Указ Президента України «Про Стратегію сталого розвитку “Україна-2020”» від 12 січня 2015 р. у частині «Дорожня карта та першочергові пріоритети реалізації Стратегії» передбачав реалізацію програми створення бренду «Україна», яка досі чекає свого часу).

\section{СПИСОК ВИКОРИСТАНИХ ДЖЕРЕЛ}

1. Гачкевич, А., Яворська, М. (2020). Ідентичний підхід до національного брендингу, Міжнародні відносини, суспільні комунікації та регіональні студії, вип. 2 (8), 57-72.

2. Khan, S., Mufti, O. (2007). The Hot History \& Cold Future of Brands, Journal of Managerial Sciences, vol. 1, N. 1, 75-87.

3. Дерев'янко, Г. (2012). Репутація підприємства в координатах інформаційної економіки XXI століття, Ефективна економіка, № 9. URL: http://www.economy. nayka.com.ua/?op=1\&z=1374.

4. Дахній, 3. (2017). Концептуалізація поняття «політична репутація держави», Політикус, вип. 3, 11-15.

5. Branding (American Marketing Association). URL: https://www.ama.org/topics/ branding.

6. Ropo, J.-P. (2009). Brand Management and Branding: Creating a Brand Strategy for ADcode. URL: https://www.theseus.fi/bitstream/handle/10024/8472/Ropo.Juha-Pekka.pdf. 
7. Бренд «Україна» (позиціонування української держави за кордоном). URL: https://www.slideshare.net/SprytkoUa/brand-book-presentation.

8. Szwajca, A. (2017). The importance of reputation of a country in the process of building its competitive advantage on the global market, Scientific Journal WSFiP, Nr. 1, 2017, 99-114.

9. Рудакова, А. (2015). Репутационный капитал государства как политический ресурс: технологии формирования и реализации: дис. ... канд. полит. наук: 23.00.02, Москва.

10. Fan, Y. (2010). Branding the nation: Towards a better understanding, Place Branding and Public Diplomacy, vol. 6, 97-103.

11. Тендит, К. (2013). Основы репутационного менеджмента: учеб. пособие, ФГБОУ ВПО «КнАГТУ»: Комсомольск-на-Амуре.

12. Федорів, Т. (2013). Сутність та інструменти репутаційного менеджменту у сфері державного управління, Державне управління та місцеве самоврядування, № $1,88-94$.

13. Jorge, D. (2004). State Branding in the 21st Century. URL: https://dl.tufts.edu/ pdfviewer/7d2795170/f4752t81n.

14. Kotler, P. et al. (1999). Marketing Places Europe: How to Attract Investments, Industries, Residents and Visitors to Cities, Communities, Regions, and Nations in Europe, Financial Times.

\section{THEORETICAL AND METHODOLOGICAL BASES OF STATES' USE OF BRANDING AND REPUTATION MANAGEMENT AS TOOLS TO MANAGE PRIVATE COMPANIES}

This article is devoted to the issue of management processes related to a nation's brand and its reputation as intangible resources. Branding and reputation management have been used to increase the success of private companies for a long time. More recently they are becoming more and more popular for developing states power in the international arena. At the same time, the existence of significant differences between those two entities requires the adaptation of traditional business approaches to the needs of states. They should serve the strengthening of a state's authority instead of the promotion of a company in markets. Given these differences, the authors examine a brand and a reputation as the objects to be managed as well as their multifaceted nature. The article discusses a question of the relationship between a nation's brand and its reputation, considering the general meaning of those terms. The authors explain the phenomena of nation branding and reputation management. The article describes some theoretical and applied problems that arise when the tools of a state's intangible resources management are used. One of the problems is the defining a target audience. The results of the study might be valuable for scholars as they continue to debate the nature of a nation's brand and its reputation as well as for state authorities and government agencies for the benefit of the entire population. 
Key words: nation branding, nation's brand, reputation management, state reputation.

\section{REFERENCES}

1. Hachkevych, A., Yavorska, M. (2020). Identychnyi pidkhid do natsionalnoho brendynhu, Mizhnarodni vidnosyny, suspilni komunikatsii ta rehionalni studii, 2 (8), $57-72$.

2. Khan, S., Mufti, O. (2007). The Hot History \& Cold Future of Brands, Journal of Managerial Sciences, 1, 1, 75-87.

3. Derevianko, H. (2012). Reputatsiia pidpryiemstva v koordynatakh informatsiinoi ekonomiky XXI stolittia, Efektyvna ekonomika, № 9. URL: http://www.economy. nayka.com.ua/?op=1\&z=1374.

4. Dakhnii, Z. (2017). Kontseptualizatsiia poniattia «politychna reputatsiia derzhavy», Politykus, 3, 11-15.

5. Branding (American Marketing Association). URL: https://www.ama.org/topics/ branding.

6. Ropo, J.-P. (2009). Brand Management and Branding: Creating a Brand Strategy for ADcode. URL: https://www.theseus.fi/bitstream/handle/10024/8472/Ropo.JuhaPekka.pdf.

7. Brend «Ukraina» (pozytsionuvannia ukrainskoi derzhavy za kordonom). URL: https://www.slideshare.net/SprytkoUa/brand-book-presentation.

8. Szwajca, A. (2017). The importance of reputation of a country in the process of building its competitive advantage on the global market, Scientific Journal WSFiP, Nr. 1, 99-114.

9. Rudakova, A. (2015). Reputatsionnyi kapytal hosudarstva kak polytycheskyi resurs: tekhnolohyy formyrovanyia y realyzatsyy: dys. ... kand. polyt. nauk: 23.00.02, Moskva.

10. Fan, Y. (2010). Branding the nation: Towards a better understanding, Place Branding and Public Diplomacy, 6, 97-103.

11. Tendyt, K. (2013). Osnovy reputatsyonnoho menedzhmenta: ucheb. posobye, FHBOU VPO «KnAHTU»: Komsomolsk-na-Amure.

12. Fedoriv, T. (2013). Sutnist ta instrumenty reputatsiinoho menedzhmentu u sferi derzhavnoho upravlinnia, Derzhavne upravlinnia ta mistseve samovriaduvannia, $1,88-94$.

13. Jorge, D. (2004). State Branding in the 21st Century. URL: https://dl.tufts.edu/ pdfviewer/7d2795170/f4752t81n.

14. Kotler, P. et al. (1999). Marketing Places Europe: How to Attract Investments, Industries, Residents and Visitors to Cities, Communities, Regions, and Nations in Europe, Financial Times.

Матеріал надійшов до редакиії 17.01.2021 p. 